\title{
Sixth grade students' attitude toward science course
}

\author{
Burcu Babaoğlan \\ Kahramanmaraş Sütçüimam University, Graduate School of Science and Technology, Kahramanmaraş, \\ Turkey, burcu-8980@hotmail.com \\ Tuğba Arıkan \\ Kahramanmaraş Sütçüimam University, Faculty of Education, Kahramanmaraş, Turkey, \\ tugbaarikan@ksu.edu.tr
}

\begin{abstract}
The aim of the research is to analyse the $6^{\text {th }}$ grade secondary school students' attitude toward science course in terms of their genders, parental professions, the number of the books they read and their interest in science. A questionnaire, specially prepared for this research, was used to examine the attitude of the students toward science course. The surveys of this study accomplished 318 sixth grade students in two different schools of Dulkadiroğlu, Kahramanmaraş. The data collection was carried out during the 2016-2017 academic years. One way analysis of variance and independent samples t test were used. According to the research results, the students' attitude toward science course were at high level and positive. The students who are interested in science course were observed to have considerably high attitude towards science course. However, no significant and meaningful relation was found between students' science course attitude and their genders and parental profession.
\end{abstract}

Keywords Attitude, Science course attitude, Science course

\section{Altıncı sınıf öğrencilerinin fen bilimleri dersine yönelik tutumları}

ÖZ Bu araştırmanın amacı ortaokul 6. sınıf öğrencilerinin fen bilimleri dersine yönelik tutum düzeyinin cinsiyetlerine, anne-baba mesleklerine, haftada okudukları kitap sayılarına ve fen bilimleri dersini sevip sevmeme durumlarına göre incelenmesidir. Araştırma kapsamında geliştirilen "Fen Bilimleri Dersine Yönelik Tutum Anketi" veri toplama aracı olarak kullanılmıştır. Veriler 2016-2017 eğitim-öğretim yılı 1. döneminde Kahramanmaraş' ta bulunan iki ortaokulda toplam 318 6.sınıf öğrencisinden toplanmıştır. Verilerin analizinde tek yönlü varyans analizi ve bağımsız gruplar $t$ testinden yararlanılmıştır. Araştırmanın sonuçlarına göre öğrencilerin fen bilimleri dersine yönelik tutumları oldukça yüksek seviyede ve olumludur. Fen bilimleri dersini seven öğrencilerin fen bilimleri dersine yönelik tutumlarının yüksek olduğu görülmüş fakat öğrencilerin fen bilimleri dersine yönelik tutum puanları ile cinsiyetleri ve anne-baba meslekleri arasında anlamlı bir ilişki bulunmamıştır.

Anahtar

Kelimeler

Tutum, Fen tutumu, Fen bilimleri dersi 


\section{INTRODUCTION}

Knowledge simply refers to the condition of knowing something. It is the information, facts, principles, skills and understanding, etc. that is acquired through education and experience. It is knowledge that has equipped man with the limitless power with which man dominates over all beings who are physically much stronger than him. Knowledge has significantly helped him to conquer the nature and this conquest has prompted human to understand nature, keep pace with changes, solve problem and increase life quality (Tezcan, 2011). Today's world requires discovering new things continuously and increasing knowledge. Science is one of the prominent fields which advancing technology is based on (İşman et al., 2002). Science is extremely important in everyday life because there is not one aspect of daily living that science has not made easier, faster or safer. Science results in technology that people rely on for health, communication, transportation etc. Scientific knowledge helps people understand the world from a cellular to a universal level. In today's world, the importance of science teaching is increasing gradually and all societiesn, particularly the developed ones, are in a continuous struggle for increasing the quality of science teaching (Milli Eğitim Bakanlığı [MEB], 2013). Because science is one of the most important gates opening to the world (Yaygin \& Sidekli, 2014).

In our daily language, the words belief, view and attitude are confused with each other and sometimes they are used interchangeably. As the number of researches about attitude increases, the attitude concept has started to gain a certain meaning and there have been some changes in its definition. Attitude towards a certain issue plays a crucial role in teaching and learning process of that issue and reaching the desired goals. Therefore, attitude is as important as interest and academic self-confidence and they should be taken into consideration for the planning of learning experience. It is a known fact that the technologies arising from science is being used more and more in our daily life and people feel themselves obliged to use these technologies in every field of their lives. We should encourage the students to be more aware of the importance of science education because by means of science education students will learn how to understand nature, collect data through scientific methods and analyze them, communicate effectively and behave responsibly and, as a result, be science literate (Akgün, 2004). Being literate individuals in science acquiring such kind of qualifications can only be achieved by increasing science interest and developing positive attitude toward science (Kozcu Çakır et al., 2007). If attitude is positive, individuals enjoy what they do more. (Bakırc1, 2010).

One of the primary aims of science education is to create individuals having positive attitude toward science course. It is necessary to start to teach science at earlier ages at schools so that students can develop positive attitude toward science course. At science, necessary atmosphere should be created in order to enable students to think and study like a scientist. By this way, students can develop positive attitude towards science course and scientific studies and improve scientific study abilities (Baran, 2013). According to (Buluş Kırıkkaya, 2011), science course teaching should be started beginning from childhood ages. Age range of 8-14 is critical period for the development of positive attitude towards science course (Șeker, 2012).

Attitude towards science course is closely related with the students' living style. For this reason, various approaches should be used to affect students' attitude positively (Moralar, 2012). Such factors as providing suitable class atmosphere together with rich materials, using research abilities, learning by doing, making science course more enjoyable and attending the class regularly have a significant influence on developing positive attitude towards science (Karakoç, 2016).

Since science course mostly comprises of abstract concepts, students usually have difficulty in understanding and concentrating on the classes. In learning process of science course, in addition to cognitive factors, attitude is also important. The aim of science teaching should be not only to make students develop positive attitude towards science course but also to acquire the knowledge and abilities needed in their daily life and later education years to adapt to changes made in education system and updated programs (MEB, 2013). For an effective science education, it is necessary to determine students' attitude toward science course and to prevent, or at least to minimize, students' developing negative attitude towards science course. Such a negative attitude against science course can affect students' success, later learnings and even their career. It is very important for students to comprehend the fact that they can make their life more meaningful by means of various activities and they need science to organize their daily life. Attitude and value, one of the seven learning domains in Science and Technology Teaching Programme, seems quite remarkable. According to this, knowledge, ability and 
developing an understanding are alone not enough for students to become Science and Technology literate. In addition to these, certain attitude and values should be developed for students (MEB, 2004). It is important that students learn science effectively and consciously to develop positive attitude towards science course that emerge as a result of people's analysis and observation of nature and natural facts to make life easier (Bozdağan \& Yalçın, 2005).

The aim of this research is to determine whether the $6^{\text {th }}$ grade secondary school students' attitude towards science course varies depending on the students' gender, parental profession, the number of books that they read weekly and being interested in science course.

In accordance with the aim of research, answers to the following questions were searched:

1 . What are $6^{\text {th }}$ grade students' attitude scores toward science course?

2. Do science course attitude scores of $6^{\text {th }}$ grade secondary school students vary in terms of gender?

3. Do science course attitude scores of the $6^{\text {th }}$ grade secondary school students vary in terms of mother's profession?

4. Do science course attitude scores of the $6^{\text {th }}$ grade secondary school students vary in terms of father's profession?

5. Do science course attitude scores of the $6^{\text {th }}$ grade secondary school students vary depending on the number of books they read weekly?

6 . Do science course attitude scores of the $6^{\text {th }}$ grade secondary school students vary depending on being interested in science course?

\section{METHODOLOGY}

In this research the attitude of $6^{\text {th }}$ grade secondary school students towards science course were analyzed in terms of various variables. We used screening model in this research. The screening model aims to interpret a situation lived in the past or exists now as it is. The sample in this research tries to define the object or the situation in its own conditions as it is (Karasar, 2009).

\section{Sample Group}

The participants of the present study were consisted of the sixth grade secondary school students of two public schools in Dulkadiroğlu-Kahramanmaraş in 2016-2017 academic years. The survey was completed with the sample that consisted of 318 students. The students volunteers were both 127 females and 191 males students. Schools were selected from same region expressing similar socioeconomic status. Details about the personal characteristics of the students who attended to the research as sample is given in the tables below.

Table1

Demographic Characters Of Sample Groups

\begin{tabular}{llll}
\hline Demographic Characters & & $\mathrm{f}$ & $\%$ \\
\hline Gender & Female & 127 & 39.9 \\
\multirow{3}{*}{ Mother' s Profession } & Male & 191 & 60.1 \\
& Housewifes & 277 & 87.1 \\
& Teacher & 3 & 0.9 \\
Father' s Profession & Other & 38 & 11.9 \\
& Self employed & 61 & 19.2 \\
& Teacher & 10 & 3.1 \\
& Engineer & 4 & 1.3 \\
& Retired & 21 & 6.6 \\
& Other & 222 & 69.8 \\
Number Of Weekly Read Books & $1-3$ & 175 & 55 \\
& $4-6$ & 69 & 21.7 \\
Being Interested In Science Course & Yes & 74 & 23.3 \\
& No & 277 & 87.1 \\
\hline
\end{tabular}

It is seen in table 1 that 127 (39.9\%) of 318 students attending to the research are female students and 191 (60.1\%) are male students. It is seen that 277 (87.1\%) students' mothers are housewives, 3 (0.9\%) 
of them are teachers and 38 (11.9\%) of them are in other job groups. It is seen that $61(19.2 \%)$ of 318 students' fathers are self-employed, 10 (3.1\%) of them are teachers, 4 (1.3\%) of them are engineers, 21 $(6.6 \%)$ of them are retired, $222(69.8 \%)$ of them are in in other job groups. It is seen that among 318 students attending to the research, there are 175 (55\%) students who read 1-3 books a week, there are 69 (21.7\%) students whose number of books read weekly change from 4 to 6 and there are $74(23.3 \%)$ students whose weekly book number is out of given ranges. It is seen 277 (87.1\%) of 318 students attending to the research like science course, $41(12.9 \%)$ of them dislike science course.

\section{Data Collection Tool}

A Science Course Attitude Questionnaire was developed in order to identify the factors that influence the secondary school students' attitude toward science course. There were 25 items in the survey to test students attitude towards science course. The content of the questionnaire was prepared by taking the science curriculum into account. For the validity checking of the questionnaire, content and construct validity were looked into. According to (Büyüköztürk, 2002), in order for a factor to measure the item, the factor load value which shows the factor's relation with that item should be 0.45 or higher. For only a few of the items can this value be lowered up to 0.30 . We based this measurement on the criteria that the factor load value should be 0.30 or higher. The analysis results showed that the science course attitude questionnaire had one dimensional structure which had 25 items. According to (Tavşancil, 2002), in factor analysis, Kaiser-Meyer-Olkin (KMO) test should be applied in order to determine the efficiency of the data obtained from the sample. KMO is a quantity related to coherence of the correlation between the sample and scale items. That KMO values are higher than 0.60 shows its acceptability (Kaiser, 1974). Kaiser-Mayer-Olkin (KMO) value and Barlett value of the Science Course Attitude Questionnaire found as 0.95 and 11433.3 respectively. These values were regarded as high. Therefore, these results showed the applicability of factor analysis and presence of correlation between the items.

Cronbach alpha reliability co-efficient was found as 0.81 , which shows high reliability level of the survey. According to (Tavşancil, 2002), cronbach alpha reliability coefficient value is acceptable if it is higher than 0.60 . The data regarding the factor and reliability analysis were summarized in the table 2 .

Table 2

The result of factor analysis, descriptive statistics, reliability co-efficient

\begin{tabular}{|c|c|c|c|c|}
\hline & $X$ & S.D. & Factor Load & Alpha \\
\hline 1. I like science course. & 4.0768 & 1.27410 & .668 & \\
\hline 2. I would like to have an occupation related to science course. & 3.2152 & 1.29517 & .364 & \\
\hline 3. I would like to use the knowledge I got from science course. & 3.8422 & 1.24033 & .598 & \\
\hline 4. Science course is a difficult subject. & 2.4802 & 1.29376 & .320 & \\
\hline 5. I think what I learn in science course is beneficial. & 4.0110 & 1.31867 & .681 & \\
\hline 6. I think I improve my knowledge through science course. & 3.9646 & 1.26495 & .686 & \\
\hline 7. I have always been interested in science course. & 3.6810 & 1.25116 & .546 & \\
\hline 8. I would like to deal with science course in my free time. & 3.2667 & 1.20449 & .577 & \\
\hline 9. I devote more time to science course than other subjects. & 2.8674 & 1.09567 & .552 & \\
\hline 10. Science course is one of the most prominent subjects that I am interested in. & 3.3328 & 1.20750 & .471 & \\
\hline 11. I think science course is an enjoyable subject. & 3.9130 & 1.99747 & .386 & \\
\hline 12. I would be glad if there were no science course at school. & 1.9586 & 1.29011 & .512 & \\
\hline 13. I think science course facilitates our daily life. & 3.7948 & 1.32635 & .551 & 0.81 \\
\hline 14. I study science course since I have to do so. & 2.3581 & 1.39015 & .469 & \\
\hline 15. Science related news on TV attract my attention. & 3.5431 & 1.34429 & .429 & \\
\hline 16. I like reading the books telling the life stories of scientists. & 3.4265 & 1.41827 & .431 & \\
\hline 17. I think science course is quite effective in learning the natural events. & 3.7314 & 1.31143 & .478 & \\
\hline 18. I like participating the debates related to science course. & 3.4426 & 1.35378 & .419 & \\
\hline 19. I am usually bored in science course. & 2.1351 & 1.26544 & .616 & \\
\hline 20. I would prefer to have more science course at school. & 3.1571 & 1.36022 & .499 & \\
\hline 21. I don’t think science course is necessary subject. & 2.0566 & 1.39168 & .456 & \\
\hline 22. I would like to be world-famous scientist. & 3.5507 & 1.49583 & .749 & \\
\hline 23. I would like to create striking inventions. & 3.7061 & 1.42663 & .680 & \\
\hline 24. I am usually withdrawn in science course. & 2.1951 & 1.34433 & .490 & \\
\hline 25. I like solving science problems. & 3.7728 & 1.35807 & .599 & \\
\hline
\end{tabular}




\section{Analysis Of Data}

Survey Data Analysis was graded as "I completely disagree 1, I disagree 2, I am indecisive 3, I agree 4, I completely agree 5". Students' gender, parental profession, the number of books they read weekly and being interested in Science course were the obtained personal information. The data received from this information was coded as numerically and processed with the packaged program. Frequency (f) and percentage distribution (\%) were calculated to describe students' personal information. Certain tables were prepared by using the findings. For the analyzing of the data, independent samples t test and one way analysis of variance statistics techniques were used. We can get at least 25 and at most 125 scores from the survey. High score obtained from the survey means that students have positive attitude towards science course.

\section{FINDINGS}

The research problem was stated as "How are $6^{\text {th }}$ grade students' attitude scores towards science course?" To answer this question, the arithmetic average and standard deviation value of the students' scores were calculated. The attitude scores of students are given below.

Table 3

The Attitude Score

\begin{tabular}{llcl}
\hline Attitude Score & $\mathrm{N}$ & $\mathrm{X}$ & $\mathrm{S} . \mathrm{D}$ \\
\hline Total & 318 & 83.62 & 15.27 \\
\hline
\end{tabular}

When table 3 is analyzed, the average of answers of 318 students given to the questionnaire was found as 83.62. According to this finding, it can be said that $6^{\text {th }}$ grade students at secondary school have quite high attitude scores.

The sub-problem in the research was stated as "Do attitude scores of $6^{\text {th }}$ grade secondary school students vary depending on gender?" Table 3 shows the results of $t$ test which was made to determine whether students' average attitude score varied depending on the variable of gender or not. To analyze the relation of gender with Science Course Attitude Questionnaire students were classified in two groups as "female" and "male" and the average, standard deviation and t values of variables according to gender groups are illustrated in below table 4 .

Table 4

$T$ Test Results Of Gender Variable

\begin{tabular}{lllllll}
\hline Gender & $\mathrm{N}$ & $\mathrm{X}$ & S.D & d.f & $\mathrm{t}$ & $\mathrm{p}$ \\
\cline { 1 - 5 } Female & 127 & 3.40 & .535 & \multirow{2}{*}{316} & \multirow{2}{*}{1.395} & \multirow{2}{*}{.164} \\
\cline { 1 - 5 } Male & 191 & 3.30 & .654 & & & \\
\hline
\end{tabular}

According to Table 4, 127 female and 191 male students involved in the study. When the scores that the students got from the science attitude questionnaire are viewed, it is found out that there is no significant difference between the attitude scores of the students in terms of gender $(\mathrm{t}(316)=1.395, p>.05)$. Judging from this finding, we can conclude that gender has no significant effect on the science attitude scores. The sub-problem was stated as "Do science attitude scores of the $6^{\text {th }}$ grade secondary school students varied in terms of mother's profession?" In order to answer this sub- problem, standard deviation and arithmetic mean values were calculated. The science attitude scores of the students and descriptive statistical results belonging to mother's profession factor were shown in Table 5.

Table 5

Descriptive Statistical Results of Mother's Profession and Variance

\begin{tabular}{llllllllll}
\hline $\begin{array}{l}\text { Mother's } \\
\text { profession }\end{array}$ & $\mathrm{N}$ & $\mathrm{X}$ & $\mathrm{SD}$ & $\begin{array}{l}\text { Variance } \\
\text { Source }\end{array}$ & $\begin{array}{l}\text { Sum Of } \\
\text { Squares }\end{array}$ & $\mathrm{DF}$ & $\begin{array}{l}\text { Mean } \\
\text { Squares }\end{array}$ & $\mathrm{F}$ & $\mathrm{p}$ \\
\hline Housewife & 277 & 3.33 & .62 & Inter-group & .766 & 2 & .383 & & \\
Teacher & 3 & 3.81 & .32 & Intra-groups & 117.468 & 315 & .373 & 1.027 & .359 \\
Other & 38 & 3.38 & .51 & Total & 118.234 & 317 & & & \\
Total & 318 & 3.34 & .61 & & & & & \\
\hline
\end{tabular}


In order to find answer to the question of whether the science attitude scores of the students varied depending on the mother's profession, we applied one-way variance analysis. The related data were shown in Table 5.

When Table 5 is viewed it is observed that the science attitude scores of the students vary depending on their mother's professions ( $p>$.05). However, this difference is not statistically significant. In fact, we can say that the scores of the students in terms of mother's profession are similar to each other. It can be concluded from this finding that the science attitude scores of the students do not change significantly depending on the mother's profession. Even if it is not statistically significant, the scores of the students whose mothers are teacher are relatively higher compared to the other students.

The sub-problem was stated as "Do science attitude scores of the $6^{\text {th }}$ grade secondary school students differentiate in terms of father's profession?" In order to answer this sub-problem, standard deviation and arithmetic mean values were calculated. The science attitude scores of the students and descriptive statistical results belonging to father's profession factor were shown in Table 6.

Table 6

Descriptive Statistical Results of Father's Profession Factor and Variance

\begin{tabular}{lllllllllc}
\hline $\begin{array}{l}\text { Father's } \\
\text { Profession }\end{array}$ & $\mathrm{N}$ & $\mathrm{X}$ & $\mathrm{SD}$ & $\begin{array}{l}\text { Variance } \\
\text { Source }\end{array}$ & $\begin{array}{l}\text { Sum Of } \\
\text { Squares }\end{array}$ & $\mathrm{DF}$ & $\begin{array}{l}\text { Mean } \\
\text { Squares }\end{array}$ & $\mathrm{F}$ & $\mathrm{p}$ \\
\hline Self employed & 61 & 3.18 & .53 & Inter-group & 2.664 & 4 & .666 & & \\
Teacher & 10 & 3.22 & .60 & Intra-groups & 115.570 & 313 & .369 & & .12 \\
Engineer & 4 & 3.16 & 1.20 & Total & 118.234 & 317 & & \multirow{2}{*}{1.804} & 8 \\
Retired & 21 & 3.27 & .55 & & & & & & \\
Other & 222 & 3.40 & .61 & & & & & \\
Total & 318 & 3.34 & .61 & & & & & \\
\hline
\end{tabular}

In order to find answer to the question of whether the science attitude scores of the students differentiate depending on the father's profession, we applied one-way variance analysis. The related data were shown in Table 6 . When Table 6 is viewed it is observed that there is no significant difference between the science attitude scores of the students depending on their father's professions $(p>.05)$. It can be concluded from this finding that father's profession has no statistically significant effect on the science attitude scores of the students. Even if it is not statistically significant, the scores of the students whose mothers are teacher have relatively higher science attitude scores. Although it is not statistically significant, the students whose fathers are teacher have relatively higher science attitude scores.

The sub-problem was stated as "Do science attitude scores of the $6^{\text {th }}$ grade secondary school students varied depending on the number of books they read weekly?" In order to answer this sub- problem, standard deviation and arithmetic mean values were calculated. The science attitude scores of the students and descriptive statistical results of the number of books they read weekly were shown in Table 7.

Table 7

Descriptive Statistical Results of the Number of Books the Students Read Weekly and Variance

\begin{tabular}{|c|c|c|c|c|c|c|c|c|c|}
\hline $\begin{array}{l}\text { Number of } \\
\text { Weekly } \\
\text { Read Books }\end{array}$ & $\mathrm{N}$ & $\overline{\mathrm{X}}$ & SD & $\begin{array}{l}\text { Variance } \\
\text { Source }\end{array}$ & $\begin{array}{l}\text { Sum Of } \\
\text { Squares }\end{array}$ & DF & $\begin{array}{l}\text { Mean } \\
\text { Squares }\end{array}$ & $\mathrm{F}$ & $\mathrm{p}$ \\
\hline $1-3$ & 175 & 3.26 & .62 & \multirow{4}{*}{$\begin{array}{l}\text { Inter-group } \\
\text { Intra-groups } \\
\text { Total }\end{array}$} & \multirow{4}{*}{$\begin{array}{l}2.972 \\
115.262 \\
118.234\end{array}$} & \multirow{4}{*}{$\begin{array}{l}2 \\
315 \\
317\end{array}$} & 1.486 & \multirow{4}{*}{4.061} & \multirow{4}{*}{.018} \\
\hline $4-6$ & 69 & 3.50 & .60 & & & & .366 & & \\
\hline Other & 74 & 3.37 & .55 & & & & & & \\
\hline Total & 318 & 3.34 & .61 & & & & & & \\
\hline
\end{tabular}

In order to find answer to the question of whether the science attitude scores of the students varied depending on the number of the books read by the students in a week, we applied one-way variance analysis. The related data were shown in Table 7. When Table 7 is viewed it is observed that there is a significant difference between the science attitude scores of the students depending on the number of the books they read weekly ( $p>$.05). It can be concluded from this finding that the number of the books 
they read weekly has statistically significant effect on the science attitude scores of the students. It has been observed that as the number of books they read weekly increases, so do their science attitude scores. The sub-problem was stated as "Do science attitude scores of the $6^{\text {th }}$ grade secondary school students differentiate depending on being interested in science course?" In order to answer this sub-problem in the survey, the answers that the students gave to the science attitude survey were evaluated and the related data were shown in Table 8.

Table 8

T-Test Results of Being Interested in Science Course

\begin{tabular}{lllllll}
\hline Being Interested In Science Course & $\mathrm{N}$ & $\mathrm{X}$ & $\mathrm{SD}$ & $\mathrm{DF}$ & $\mathrm{t}$ & $\mathrm{p}$ \\
\hline Yes & 277 & 3.46 & .515 & \multirow{2}{*}{316} & \multirow{2}{*}{10.428} & \multirow{2}{*}{.000} \\
No & 41 & 2.54 & .607 & & & \\
\hline
\end{tabular}

When we look through the data in Table 8, we observe that there is significant difference between the scores that the students got from science course attitude questionnaire depending on being interested in science course $(\mathrm{t}[316]=10.428, p<.01)$. We can conclude from this finding that the attitude of the students who are interested in science course is more positive than those who are not interested in science course. We also evaluated the correlation between the scores that the $6^{\text {th }}$ grade secondary school students got from science course attitude questionnaire and being interested in science course and the results of related data analysis are shown in Table 9.

Table 9

Correlation Between Attitude and Interest

\begin{tabular}{llll}
\hline & & Attitude & Interest \\
\hline Attitude & $\mathrm{r}$ & 1 & .691 \\
& $\mathrm{p}$ & & 000 \\
& $\mathrm{~N}$ & 318 & 318 \\
Interest & $\mathrm{r}$ & .691 & 1 \\
& $\mathrm{p}$ & 000 & \\
& $\mathrm{~N}$ & 318 & 318
\end{tabular}

When we look through the table 9 , we observe that there is a positive and statistically significant relation between students' being interested in science course and the scores they got from the science course attitude questionnaire $(p<.01)$, which means that the students who are interested in science course have relatively higher science course attitude scores and they have positive attitude toward science course.

\section{DISCUSSION and CONCLUSION}

The aim of the research is to determine whether the $6^{\text {th }}$ grade secondary school students' attitude toward science course varies depending on the students' gender, parental profession, the number of books that they read and being interested in science course and the results derived from the findings are summarized below.

Although the female students in the study had higher average science course attitude scores with respect to the male students, it was not statistically significant. Therefore, it can be concluded that gender factor has no significant effect on the science course attitude scores of the $6^{\text {th }}$ grade secondary school students. We saw similar results in the literature. According to the study conducted by (Güden \& Timur, 2016), gender has no significant effect on the science attitude scores of the secondary school students at different levels $\left(5^{\text {th }}, 6^{\text {th }}, 7^{\text {th }}, 8^{\text {th }}\right.$ grades $)$. (Kozcu Çakır et al., 2007) concluded in their study that according to independent t-test results there is no significant difference between the gender factor and science attitude scores of the students. Similarly, as a result of the data analysis in their study, (Sinan, Şardağ, Salifoğlu, Çakır, \& Karabacak, 2014) stated that gender had no effect on science attitude scores of the secondary school students ( $5^{\text {th }}, 6^{\text {th }}, 7^{\text {th }}, 8^{\text {th }}$ grades $)$. It might be due to the fact that there is a coeducation system in our country and teachers try to educate the students regardless of their gender. The results of other studies which investigated the relation between the attitude scores and gender also resembled each other. According to the study of (Serin, Kesercioğlu, Saracaoğlu, \& Serin, 2003) gender 
had no significant effect on the students' attitude towards science in $4^{\text {th }}$ grade students in department of primary school teaching and science teaching. According to the results of the studies carried out by (Ersoy \& Ergün, 2014) with 512 primary school teaching students in Turkey, Netherlands and Romania and by (Elkonca, Şevgin \& Ceyhan, 2014) with 605 secondary school students, gender factor had no effect on the students' attitude toward science. (Akman, İzgi, Bağçe \& Akıllı, 2007) and (Turhan, Aydoğdu, Şensoy \& Yıldırım, 2008) stated in their studies that there was no significant difference between the Science attitude scores and gender variable. (Can \& Dikmentepe, 2015) stated that there was no significant difference between the students' attitude to science and technology and science experiments in terms of gender. (Kaya \& Böyük, 2011) concluded that gender had no significant and meaningful effect on the second stage primary education students' attitude against science and technology classes and science experiments. (Böyük, Koç, Erol \& Engin, 2013) stated that the second stage primary education students' attitude against science and their future planning were not influenced by gender variable. (Can \& Şahin, 2015) studied the preschool teacher candidates' attitude towards science and science teaching and found no significant relation between their science attitude and gender. There is no statistically significant difference between the science course attitude scores of the $6^{\text {th }}$ grade secondary school students and mother's profession ( $p>.05)$. In fact, it can be said that the scores of the students were nearly the same with each other. From this finding, we can conclude that the science course attitude scores of the $6^{\text {th }}$ grade secondary school students were not affected from mother's profession. Even though it does not a have statistical significance, the students whose mothers are teacher had relatively higher science course attitude scores compared to the students whose mothers are from other occupational groups. The average science course attitude scores of the $6^{\text {th }}$ grade secondary school students didn't differentiate significantly depending on father's professions ( $p>05$ ). From this finding, we can conclude that the science course attitude scores of the $6^{\text {th }}$ grade secondary school students are not affected from father's profession. Although it is not statistically significant, the students whose fathers are teacher had relatively higher science course attitude scores compared to the students whose fathers are from other occupational groups. There are some similar studies in literature. For instance, according to the study of (Serin et al., 2003) parental professions of the students didn't affect their attitude towards science course in $4^{\text {th }}$ grade students in department of primary school teaching and science teaching. (Güden \& Timur, 2016) said in their study that father's professions did not effect the attitude of the $6^{\text {th }}$ grade secondary school students. Although parents experience so many difficulties in their occupation life, they usually prefer not reflecting such negative aspects of their profession to their children and such an approach might have prevented the students' attitude towards science course from being affected negatively. The students' developing positive attitude towards science course might also be due to the fact that the parents encourage their children or helping them in science activities.

The average science course attitude scores of the $6^{\text {th }}$ grade secondary school students varied significantly depending on the number of the books they read in a week ( $p>.05$ ). It can be concluded from this finding that the number of the books read by students weekly had a significant effect on the students' science course attitude scores. It was observed that as the number of the books read by the students increased, their average science course attitude scores increased as well. It can be explained by the today's students' being more aware of the importance of reading book.

We made simple correlation analysis in order to determine whether there is a significant relation between the average science course attitude scores the students get and being interested in science course. As a result of the data analysis, we found out that there was a significant and positive relation between the average science course attitude scores the students got and being interested in science course $(p<.01)$. This result shows that the students who are interested in science course had higher science course attitude scores from the questionnaire. We concluded from the study that science course interest had a significant effect on students' developing positive attitude towards science course. (Yenice \& Saydam, 2010) concluded in their study that $8^{\text {th }}$ grade students had high attitude scores. According to the study of (Serin et al., 2003), $4^{\text {th }}$ grade students in department of science teaching had positive attitude against science course. According to the study of (Güden \& Timur, 2016), secondary school students had considerably high attitude against science course.

The suggestions that we can make as a result of the study might be as follows:

Further studies should be carried out to study demographic characteristics.

Science course contents should be enriched with interesting activities in order to improve the students' attitude toward science. 
The contents of science course should be associated with other disciplines in such a way that they can improve the students' attitude toward science course.

\section{REFERENCES}

Akgün, Ş. (2004). Fen bilgisi öğretimi. Ankara: Nasa Yayınları.

Akman, B., İzgi, Ü., Bağçe, H., \& Akıllı, H. İ. (2007). İlköğretim öğrencilerinin fen'e karşı tutumlarının sınav kayg1 düzeylerine etkisi. Ĕgitim ve Bilim Dergisi, 32 (146), 3-11.

Bakırc1, H. (2010). Üniversiteler düzeyinde fen bilgisi öğretmen adaylarının branşlara (fizik- kimya- biyoloji) karş1 tutumlarının incelenmesi. Yüzüncü Yll Üniversitesi Fen Bilimleri Enstitüsü Dergisi, 15 (1), 75-81.

Baran, B. (2013). Bilim tarihi ve felsefesi ögretim metodunun fen bilimlerine yönelik tutum ve motivasyon üzerine etkisi (Yüksek lisans tezi). Gaziosmanpaşa Üniversitesi , Tokat.

Bozdoğan, A. E., \& Yalçın, N. (2005). İlköğretim 6., 7. ve 8. sınıf öğrencilerinin fen bilgisi derslerindeki fizik konularına karşı tutumları. Gazi Üniversitesi Kırşsehir Eğitim Fakültesi Dergisi, 6 (1), 241-247.

Böyük, U., Koç, A., Erol M., \& Engin S. (2013). İlköğretim ikinci kademe öğrencilerinin bilim ve teknolojiye yönelik tutumları ve gelecekle ilgili planları. Erciyes Üniversitesi Fen Bilimleri Enstitüsü Dergisi, 29 (2), 178-184.

Buluş Kırıkkaya E. (2011). “Grade 4 to 8 primary school students’ attitudes towards science: science enthusiasm”. Educational Research and Reviews, 6 (1), 374-382.

Büyüköztürk, Ş. (2008). Sosyal bilimler için veri analiz el kitabı. Ankara: Pegem Yayınevi.

Can, M., \& Çiğdem Ş. (2015). Okul öncesi öğretmen adaylarının fene ve fen öğretimine yönelik tutumlarının incelenmesi, Abant İzzet Baysal Üniversitesi Ë̆itim Fakültesi Dergisi, 15 (2), 13-26.

Can, Ş. \& Dikmentepe, E. (2015). Ortaokul öğrencilerinin fen ve teknoloji dersi ile fen deneylerine yönelik tutumlarının araştırılması (Muğla ili örneği). MSKU Eğitim Fakültesi Dergisi MSKU Journal of Education, 2 (1), 44-58.

Ersoy, Ö., \& Ergün, M., (2014). Sınıf öğretmenliği adaylarının fen bilimlerine karşı tutumları: Türkiye, Hollanda ve Romanya örneği. Türk Fen Eğitimi Dergisi, 11 (2), 85-109.

Güden, C., \& Timur, B. (2016). Ortaokul öğrencilerinin fen bilimlerine yönelik tutumlarının bazı değişkenlere göre incelenmesi (Çanakkale örneği). International Journal of Active Learning (IJAL), 1 (1), 49-72.

İşman A., Baytekin Ç., Balkan, F., Horzom, M. B., \& Kıyıcı M. (2002). Fen bilgisi eğitimi ve yapısalcı yaklaşım. The Turkish Online Journal of Educational Technology -TOJET ,1 (1): 47-53.

Kaiser, H. F. (1974). An index of factorial simplicity, Psychometrika, 39 (1), 31-6.

Karakoç, T., (2016). Görme yetersizliği olan öğrencilerin araştırmaya dayalı öğrenme yaklaşımı modellerinden rehberli keşfetme modelinin deneysel işlem becerilerine, akademik başarllarına ve fen bilimleri dersine yönelik tutumlarına etkisi (Doktora tezi). Gazi Üniversitesi, Ankara.

Karasar, N. (2009). Bilimsel Araştırma Yöntemi. Adana: Nobel Yayın Dağıtım

Kaya, H., \& Böyük, U. (2011). İlköğretim II. kademe öğrencilerinin fen ve teknoloji dersine ve fen deneylerine karşı tutumları, Tübav Bilim Dergisi, 4 (2), 120-130.

Kayri, M., Elkonca, F., Şevgin, H., \& Ceyhan, G., (2014). Ortaokul öğrencilerinin fen ve teknoloji dersine yönelik tutumlarının CHAID analizi ile incelenmesi. Ë̆itim Bilimleri Araştırma Dergisi, 4 (1), $301-316$.

Kozcu Çakır, N. Şenler, B., \& Göçmen Taşkın, B. (2007). İlköğretim II. kademe öğrencilerinin fen bilgisi dersine yönelik tutumlarının belirlenmesi. Türk Eğitim Bilimleri Dergisi, 5 (4), 637- 655.

MEB, (2004). İlköğretim fen ve teknoloji dersi 4. ve 5. sinıf öğretim programi, Ankara.

MEB, (2012). İlköğretim fen ve teknoloji dersi (6, 7 ve 8. sinfflar) öğretim programl, Ankara.

MEB, (2013). Ortaokul matematik dersi (5, 6, 7 ve 8. siniflar) ögretim programı, Ankara.

Moralar, A., (2012). Fen eğitiminde probleme dayalı ögrenme yaklaşımının akademik başarı, tutum ve motivasyona etkisi (Yüksek Lisans Tezi). Trakya Üniversitesi, Edirne.

Serin, O., Kesercioğlu, T., Saracaoğlu, A. S., \& Serin, U. (2003). Sınıf öğretmenliği ve fen bilgisi öğrencilerinin fen bilimlerine yönelik tutumları. M.Ü. Atatürk Eğitim Fakültesi Eğitim Bilimleri Dergisi, 17 (17), 75-86.

Sinan, O., Şardağ, M., Salifoğlu, A., Çakır, C., \& Karabacak Ü. (2014). İlköğretim öğrencilerinin fen tutumları ve özyeterliliklerinin incelenmesi. Necatibey Eğitim Fakültesi Elektronik Fen ve Matematik Eğitimi Dergisi (EFMED), 8 (1), 68-100.

Şeker, F., (2012). İlköğretim fen ve teknoloji dersinde tamamlayıcı ölçme ve değerlendirme yaklaşımlarının tutum ve başarlya etkisi (Yüksek lisans tezi). Akdeniz Üniversitesi, Antalya.

Tavşancıl, E. (2002). Tutumların ölçülmesi ve spss ile veri analizi. Ankara: Nobel Yayınları.

Tezcan, G., (2011). 6. Sinıf fen ve teknoloji dersi ögretim programı ünite konularına yönelik bilimsel sürę̧ becerileri testinin geliştirilmesi (Yüksek lisans tezi). Çanakkale Onsekiz Mart Üniversitesi, Çanakkale.

Turhan, F., Aydoğdu, M., Şensoy, Ö. ve Yıldırım, H. İ., (2008). İlköğretim 8. sınıf öğrencilerinin bilişsel gelişim düzeyleri, fen bilgisi başarıları, fen bilgisine karşı tutumları ve cinsiyet değişkenleri arasındaki ilişkinin incelenmesi. Kastamonu Eğitim Dergisi, 16 (2), 439-450. 
Yaygın, S., \& Sidekli, S. (2014). Öğrencilerin fen ve teknoloji dersine karşı tutumlarındaki değişim: bir yıllık takip. Erzincan Üniversitesi Ĕ̆itim Fakültesi Dergisi, 16 (2), 121-140.

Yenice, N., \& Saydam, G. (2010). 8th grade students' science attitudes and views about nature of scientific knowledge. Journal of Qafquz University, 29 (1), 89-97. 


\section{TÜRKÇE GENIŞLETILMIŞ ÖZET}

Bireylerin çalışmaları sonucu edinilen bilgi birikimleri dünyayı anlamayı, teknolojiye ayak uydurmayı, problem çözmeyi ve yaşam kalitesini arttırmayı sağlamaktadır (Tezcan, 2011). İçinde bulunduğumuz çağ yeni şeyler keşfetmeyi ve bilgiyi arttırmayı gerektirmektedir. Gelişen teknolojinin temelinin atıldığı alan ise fen bilimleridir (İşman, Baytekin, Balkan, Horzom, \& Kıyıcı, 2002).

Günlük dilde inanç, görüş ve tutum kelimeleri birbiriyle karıştırılarak, bazen de biri diğerinin yerine geçmek üzere kullanılmaktadır. Tutumlar üzerindeki araştırmalar ilerledikçe tutum kavramı daha kesin bir anlam kazanmış, tanımında da değişiklikler olmuştur. Tutum, öğrenen bireylerin istendik yönde hedeflere ulaşmasını sağlayan önemli duyuşsal öğelerden biridir. Zira öğrenme yaşantılarının planlanmasında ilgi ve akademik özgüven kadar tutumların da dikkate alınması gerekmektedir. Fen bilimleri eğitimi alan öğrencilerin çevreleri ve dünyayla aktif bir biçimde ilgilenen, anlamlı sorular sorup gözlem ve deneylerle veriler toplayan ve bunları analiz edebilen, edindikleri bilgileri söz ve yazıya dökerek başkalarıyla uygarca iletişim kurabilen, sorumlu davranan ve sorumluluklarının bilincinde, bilgili ve yetenekli bireyler olarak yetiştirilmesi; onların yeterli düzeyde fen alanında okur-yazar bireyler hâline gelmesi ile mümkündür (Akgün, 2004). Fen alanında okur-yazar bireylerin bu niteliklere sahip olması; fen konularına karşı ilgi duymaları ve olumlu tutum geliştirmeleriyle sağlanabilir (Kozcu Çakır, Şenler, \& Göçmen Taşkın, 2007). Tutumların olumlu olması durumunda birey yaptığı işten doyum alır (Bakırc1, 2010).

Fen bilimleri eğitiminin temel amaçlarından bir diğeri de, fen bilimleri dersine yönelik olumlu tutum sergileyen bireyler yetiştirmektir. Çocuklarda fen bilimleri dersine yönelik olumlu tutum kazandırılması açısından fen bilimleri dersinin okullarda erken verilmeye başlanması önemlidir. Fen bilimleri dersinde öğrencilerin bilim insanı gibi düşünmelerine ve bilim insanı gibi çalışmalarına ortam sağlanabilir. $\mathrm{Bu}$ sayede öğrencilerin bilimsel süreç becerileri geliştirilerek bilimsel çalışmalara ve fen bilimleri dersine olumlu tutum geliştirmesi sağlanabilir (Baran, 2013). (Buluş Kırıkkaya 2011) 'ya göre olumlu tutumların gelişmesi için çocukluk yaşlarından itibaren fen eğitimine başlanmalıdır. 8-14 yaşları arası fen bilimleri dersine karşı tutumların gelişmesinde kritik dönemdir (Şeker, 2012).

Fen bilimleri dersine yönelik tutumlar öğrencilerin yaşantılarının ürünüdür. Bu nedenle öğrencilerin tutumlarını geliştirmek için kullanılan yaklaşımların boyutları arttırılmalıdır (Moralar, 2012). Öğrencilerin fen bilimleri dersini sevebilmeleri, derse etkin olarak katılabilmeleri için zengin materyallerle, araştırma becerilerinin kullanıldığ 1 , yaparak yaşayarak öğrenme etkinlikleriyle ders ortamı sağlanması derse karşı olumlu tutumu etkilemektedir (Karakoç, 2016).

Fen bilimleri dersi çoğunlukla soyut kavramlardan oluşan bir derstir. Kavramların soyut olması öğrencilerin dersi anlamada zorluk çekmelerine neden olmaktadır. Öğrenme sürecinde öğrencilerin fen bilimleri dersine yönelik başarılarının zihinsel faktörlerin yanında tutum gibi duyuşsal faktörler de etkilidir.

İnsanların yaşamı daha kolay hale getirmeleri, doğayı ve doğa gerçeklerini gözlemlemeleri ve incelemeleri sonucu ortaya çıkan davranışlar; öğrencilerin fen bilimlerine karşı olumlu tutum kazanması fenin etkili ve bilinçli öğrenilmesi açısından önemlidir (Bozdağan \& Yalçın, 2005).

$\mathrm{Bu}$ çalışmada ortaokul 6.sınıf öğrencilerinin fen bilimleri dersine yönelik tutumlarının cinsiyet, annebaba mesleği, haftada okunan kitap sayısı, fen bilimleri dersini sevme değişkenlerine göre farklılık gösterip göstermediğinin belirlenmesi amaçlanmıştır. Araştırmada tarama modeli kullanılmıştır. Araştırmanın örneklemini Kahramanmaraş ili Dulkadiroğlu ilçesine bağl1 2 farklı ortaokulda öğrenim görmekte olan toplam 318 altıncı sınıf öğrencisi oluşturmaktadır. Öğrencilerin fen bilimleri dersine yönelik tutum puanlarının belirlenmesinde çalışma kapsamında araştırmacı tarafından geliştirilen 5' li likert tipi "Fen Bilimleri Dersine Yönelik Tutum Anketi" kullanılmıştır. Fen Bilimleri Dersine Yönelik Tutum Anketi öğrencilerin fen bilimleri dersine yönelik tutumlarını değerlendirmek için geliştirilmiştir. Anket maddeleri fen bilimleri dersi içeriği temel alınarak hazırlanmıştır. Anketten en az 25, en fazla 125 
puan alınabilmektedir. Anketten alınan yüksek puanlar öğrencilerin fen bilimleri dersine yönelik olumlu tutuma sahip olduğunu göstermektedir. Çoğunlukla olumlu ifadelerden oluşan anket maddelerinin güvenirlik katsayısı cronbach alpha 0.818 olarak bulunmuştur. Elde edilen bu güvenirlik katsayısı testin güvenirliğinin yüksek olduğunu göstermektedir.

Fen Bilimleri Dersine Yönelik Tutum Anketinin Kaiser- Mayer-Olkin (KMO) değerinin 0.95, Barlett değerinin 11433.3 olduğu görülmektedir. Buna göre sonuçlar, faktör analizinin uygulanabilirliğini ve maddeler arası korelasyonun olduğunu göstermektedir. Araştırma kapsamında öğrencilerin fen bilimleri dersine yönelik tutumlarını değerlendirmek için tek yönlü varyans analizi ve bağımsız örneklemler t testi kullanılmıştır. Araştırmaya katılan 318 öğrencinin Fen Bilimleri Dersine Yönelik Tutum Anketi' ne verdikleri cevapların ortalaması 83.62 bulunmuştur. Bu bulguya göre ortaokul 6.sınıf öğrencilerinin tutum puanlarının oldukça yüksek seviyede olduğu söylenebilir. Araştırmaya 127 kız, 191 erkek öğrenci katılmıştır. Öğrencilerin Fen Bilimleri Dersine Yönelik Tutum anketinden aldıkları puanlar incelendiğinde tutum puanları arasında cinsiyet değişkenine göre anlamlı bir fark olmadığı görülmektedir $(\mathrm{t}(316)=1.395, \mathrm{p}>.05)$. Bu bulguya göre fen bilimleri dersine yönelik tutum puanının cinsiyete göre değişmediği söylenebilir. Anne ve baba mesleği değişkenlerine göre öğrencilerin fen bilimleri dersine yönelik tutumlarının birbirine yakın olduğu söylenebilir. Bu bulguya göre fen bilimleri dersine yönelik tutum puanının anne ve baba mesleğine göre değişmediği söylenebilir. Öğrencilerin haftada okudukları kitap sayısı arttıkça fen bilimleri dersine yönelik tutum puanlarının arttığı görülmektedir.

Çalışmada elde edilen verilerin analizi sonucu, öğrencilerin fen bilimleri dersine yönelik tutum puanları ve bu dersi sevmeleri arasında yüksek düzeyde, pozitif ve anlamlı bir ilişkinin olduğunu göstermiştir. Bu durum fen bilimleri dersini seven öğrencilerin fen bilimleri dersine yönelik tutum puanlarının yüksek olduğunu, fen bilimleri dersini seven öğrencilerin olumlu tutuma sahip olduğunu göstermektedir. 